\title{
Pengaruh Peta Konsep Melalui Model Pembelajaran Kooperatif Tipe Think Pair Share (TPS) Terhadap Hasil Belajar Siswa Kelas X SMA Negeri 1 Liliriaja Pada Materi Pokok Hidrokarbon
}

\author{
The Influence Of Concept Mapping Through Cooperative Learning Model \\ Type Think Pair Share (TPS) Towards Result Study Of Student Class X SMA \\ Negeri 1 Liliriaja in Hydrocarbons Topic
}

\author{
${ }^{1)}$ I Wayan Putra Ariwirawan, ${ }^{2)}$ Muh. Yunus, ${ }^{3)}$ Halimah Husain \\ 1,2,3) Jurusan Kimia Fakultas Matematika dan Ilmu Pengetahuan Alam \\ Universitas Negeri Makassar, Jl. Dg Tata Raya Makassar, Makassar 90224 \\ Email: wayanputraa93@gmail.com
}

\begin{abstract}
ABSTRAK
Penelitian ini adalah penelitian eksperimen dengan jenis penelitian quasy experiment yang bertujuan untuk mengetahui ada tidaknya pengaruh peta konsep melalui model pembelajaran kooperatif tipe Think Pair Share (TPS) terhadap hasil belajar siswa kelas X SMA Negeri 1 Liliriaja pada materi pokok hidrokarbon. Desain penelitian yang digunakan adalah "pretestposttest contol group design". Populasi penelitian ini adalah siswa kelas X SMA Negeri 1 Liliriaja yang terdiri dari 13 kelas yang terdistribusi atas 1 kelas khusus dan kelas X1-X9. Sedangkan sampel penelititan dipilih secara acak yaitu kelas X9 sebagai kelas eksperimen dan kelas X1 sebagai kelas kontrol dengan jumlah siswa masing-masing 30 orang. Kelas eksperimen dibelajarkan dengan model pembelajaran kooperatif tipe TPS dengan media peta konsep, sedangkan kelas kontrol dibelajarkan dengan model pembelajaran kooperatif tipe TPS dengan media power point. Variabel bebas pada penelitian ini adalah media pembelajaran peta konsep melalui model pembelajaran kooperatif tipe TPS dan variabel terikatnya yaitu hasil belajar. Pengambilan data hasil belajar dilakukan dengan pemberian pretest dan posttest. Data hasil belajar yang diperoleh dianalisis dengan menggunakan statistik deskriptif dan statistik inferensial. Hasil analisis menunjukkan nilai rata-rata hasil belajar siswa kelas eksperimen pada pretest dan posttest berturut-turut yaitu 16,56 dan 76,73 dengan rata-rata $\mathrm{N}$-Gain 0,725 dan kelas kontrol yaitu 25,27 dan 73,03 dengan rata-rata N-Gain 0,613. Hasil pengujian hipotesis menggunakan uji-t diperoleh nilai thitung $=3,002$ dan pada taraf signifikan $\alpha=0,05$ dengan $\mathrm{dk}=58$ diperoleh ttabel $=2,0017$. Oleh karena thitung > ttabel, maka $\mathrm{H} 1$ diterima dan $\mathrm{H} 0$ ditolak. Hal tersebut menunjukkan bahwa ada pengaruh media peta konsep melalui model pembelajaran koperatif tipe think pair share terhadap hasil belajar siswa.
\end{abstract}

Kata kunci: Peta Konsep, TPS, Hasil Belajar, N-Gain 


\begin{abstract}
This study is an experiment research with quasi-experimental type aimed to know the positif influence of concept mapping through cooperative learning model type (TPS) towards learning outcome student class X SMA Negeri 1 Liliriaja in Hydrocarbons topic. The study design was "pretest-posttest control group design". The population in this study were all class X SMA Negeri 1 Liliriaja which consists of 13 classes which distributed on one special class and class $\mathrm{X}_{1}-\mathrm{X}_{9}$. While the sample where chosen by random, the class has been chosen was $\mathrm{X}_{9}$ as experimental class and $\mathrm{X} 1$ as control class, with number of student in each class are 30 people. The experimental class was taught with cooperative learning model type TPS with concept mapping media, while the control class taught with cooperative learning model type TPS with power point media. The independent variable in this study is concept mapping media through cooperative learning model type TPS, and the dependent variable is the result of learning. Data retrieval of learning outcome achieved by giving a pretest and posttest. Learning outcome were analyzed using descriptive statistics and inferential statistics. The analysis showed the average value of student learning outcomes experiment class in the pretest and posttest are 16,56 and 76,73, respectively, with an average $\mathrm{N}-$ Gain 0,725 and control class, 25,27dan 73,03 with an average of $0,613 \mathrm{~N}$ Gain. The results of hypothesis testing using t-test values obtained at $\mathrm{t}_{\text {count }}=3,002$ and $\alpha=0.05$ significance level with $\mathrm{df}=58$ obtained $t_{\text {table }}=2,0017$. Therefore, $t_{\text {count }}>t_{t a b l e}$, then $H_{1}$ is accepted and $H_{0}$ is rejected. It shows that there are influence concept mapping through cooperative learning model type think pair share to student outcome learning.
\end{abstract}

Keywords: Concept mapping, TPS, Learning Outcome, N-Gain

\section{PENDAHULUAN}

Pembelajaran dapat diartikan sebagai kegiatan menyampaikan pesan berupa pengetahuan, keterampilan, dan sikap dari guru kepada siswa. Berdasarkan pengertiannya maka keberhasilan proses pembelajaran sangat dipengaruhi oleh guru dan oleh peserta didik itu sendiri. Untuk itu guru perlu mendesain proses belajar mengajar menjadi menyenangkan dan membuat siswa menjadi berperan aktif dalam proses pembelajaran. Jika hal ini terjadi maka tujuan pembelajaran yang direncanakan dapat tercapai dengan mudah, begitu pula tujuan pendidikan nasional.

Berdasarkan hasil observasi yang dilakukan di SMA Negeri 1 Liliriaja kabupaten Soppeng, diperoleh informasi bahwa dalam proses pembelajaran siswa kurang berperan aktif, cenderung hanya mendengarkan penjelasan yang diberikan oleh guru 
tanpa adanya timbal balik dari siswa. Hal tersebut menyebabkan hasil belajar siswa menjadi rendah, hal ini dibuktikan dengan rendahnya tingkat ketuntasan kelas yang hanya sebesar $30 \%$ saja dengan kriteria ketuntasan minimum (KKM) 75.

Setelah dilakukan observasi lebih lanjut diperoleh infomasi bahwa guru kimia disekolah itu menggunakan metode pembelajaran langsung dalam proses pembelajaran, dimana model pembelajaran langsung yang digunakan kurang memberikan kesempatan kepada siswa untuk mengemukakan pendapat mereka. Berdasarkan lembar observasi yang diberikan kepada siswa diperoleh informasi bahwa siswa lebih senang belajar kelompok dari pada belajar individu, alasannya karena ketika belajar kelompok mereka bisa bertukar pendapat dan bisa saling bekerjasama untuk menyelesaikan suatu permasalahan, khususnya dalam mata pelajaran kimia, namun guru kimia mereka jarang memberikan pembelajaran dalam bentuk kelompok.

Salah satu inovasi yang dapat dilakukan untuk mengatasi masalah tersebut yaitu dengan menggunakan model pembelajaran kooperatif. Model pembelajaran kooperatif merupakan model pembelajaran yang menekankan pada kerja sama siswa dalam bentuk kelompok-kelompok kecil (Slavin, 2009). Terdapat bebagai jenis model pembelajaran kooperatif yagn ada saat ini sebagai contoh yaitu model pebelajaran kooperataif tipe JIGSAW, NHT, STAD, TPS dan lain sebagainya. Salah satu model pembelajaran yang dapat mengaktifkan siswa yaitu model pembelajaran kooperatif tipe think pair share (TPS), dimana model pembelajaran ini lebih menekankan pada kerja sama kelompok dalam bentuk pasangan.

Media pembelajaran dapat membantu keefektifan dari model pembelajaran kooperatif tipe TPS. Salah satu media yang dapat digunakan untuk mengatasi masalah tersebut ada media peta konsep. Media pembelajaran peta konsep merupakan suatu alat yang menunjukkan hubungan antar satu konsep dengan konsep yang lain berdasarkan proporsinya (Yogihati, 2010).

Media peta konsep dapat menjadi salah satu alternatif untuk mengatasi kekurangan dari model pembelajaran kooperatif tipe TPS karena dengan menggunakan media peta konsep penyampaian materi pelajaran menjadi lebih sederhana dan mudah dipahami oleh siswa. Ketika siswa sudah memahami materi pelajaran dengan baik maka masalah yang diberikan guru pada tahan Think akan dapat diselesaikan dengan mudah oleh siswa.

\section{METODE PENELITIAN}

Penelitian ini merupakan penelitian eksperimen semu (quasi experimental) berbentuk PretestPosttest Control Grup Design. Penelitian ini menggunakan dua variabel yaitu variabel bebas dan variabel terikat. Variabel bebas yaitu media pembelajaran peta konsep melalui model pembelajaran kooperatif tipe Think Pair Share, sedangkan variabel terikat yaitu hasil belajar siswa kelas X SMA Negeri 1 Liliriaja. 
Populasi dalam penelitian ini adalah seluruh kelas $\mathrm{X}$ (sepuluh) SMAN 1 Liliriaja tahun pelajaran 2015/2016 yan terdiri dari 13 kelas,yang terdistribusi menjadi 1 kelas khusus dan kelas X1-X12. Sampel yaitu kelas X9 sebanyak 30 siswa sebagai kelas eksperimen dan kelas X1 sebanyak 30 siswa sebagai kelas kontrol.

Pembelajaran berlangsung selama 5 kali pertemuan belaja rmengajar dan 1 pertemuan untuk posttest dimana setiap pertemuannya dilaksanakan selama 2 jam pelajaran. Sedangkan untuk pretest dilaksanakan diluar jam pembelajaran.

Teknik pengumpulan data dilakukan dengan pemberian tes awal (pretest) dan tes akhir (posttest) untuk kelas eksperimen dan kelas kontrol.

Instrumen hasil belajar yang digunakan adalah objektif tes dengan bentuk pilihan ganda sebanyak 20 soal yang dinyatakan valid oleh ahli dan telah melalui validasi item. Lembar observasi digunakan untuk melihat keterlaksanaan proses pembelajaran, dimana lembar observasi ini diisi oleh observer setelah melalui validasi ahli.

Tabel 1. Kriteria Ketuntasan Belajar Kimia Kelas X SMAN 1 Liliriaja

\begin{tabular}{cc}
\hline Nilai & Keterangan \\
\hline$\geq 75$ & Tuntas \\
$<75$ & Tidak Tuntas \\
\hline
\end{tabular}

Teknik analisis data yang digunakan yaitu analisis deskriptif yang mendeskripsikan karakteristik distribusi nilai hasil belajar siswa kelas X SMAN 1 Liliriaja pada kelas eksperimen dan kelas kontrol, ditampilkan dalam bentuk rata-rata, skor maksimum, skor minimum, standar deviasi, varians, serta tabel distribusi frekuensi, dan analisis inferensial yang digunakan untuk menguji hipotesis penelitian menggunakan uji-t. Sebelum pengujian hipotesis terlebih dahulu dilakukan pengujian dasar-dasar analisis, yakni uji normalitas dan uji homogenitas. Data yang digunakan untuk analisis inferensial ialah data hasil gain score yaitu besarnya peningkatan pretest ke posttest. Pengujian hipotesis dilakukan dengan uji pihak kanan.

Keterangan:

$$
\mathrm{H}_{0}: \mu_{1} \leq \mu_{2} \quad \mathrm{H}_{1}: \mu_{1}>\mu_{2}
$$

$\mathrm{H}_{0}$ : Tidak ada pengaruh media peta konsep melalui model pembelajaran koperatif tipe think pair share terhadap aktivitas dan hasil belajar siswa kelas X SMA Negeri 1 Liliriaja Studi Pokok Pada Materi hidrokarbon.

$\mathrm{H}_{1}$ : Ada pengaruh media peta konsep melalui model pembelajaran koperatif tipe think pair share terhadap aktivitas dan hasil belajar siswa kelas X SMA Negeri 1 Liliriaja Studi Pokok Pada Materi hidrokarbon

$\mu_{1}$ : Nilai rata-rata N-gain siswa pada kelas experimen.

$\mu_{2}$ : Nilai rata-rata $\mathrm{N}$-gain siswa pada kelas kontrol.

\section{HASIL DAN PEMBAHASAN}

A. Hasil Penelitian

1. Deskripsi Hasil Belajar Siswa Kelas Eksperimen dan Kontrol

Nilai hasil belajar siswa kelas eksperimen dan kelas kontrol 
berdasarkan hasil analisis deskriptif sebagai berikut.

Melihat besarnya perbedaan nilai hasil belajar dari kelas eksperimen dan kontrol yang cukup besar, ini dapat menggambarkan bahwa terdapatnya perbedaan yang besar antara kelas eksperimen dengan kelas kontrol.

Kategori ketuntasan minimal di SMAN 1 Liliriaja yaitu 75, siswa yang tergolong tuntas pada kelas eksperimen yaitu 25 siswa atau
$83,33 \%$ sedangkan untuk kelas kontrol 23 siswa atau $76,67 \%$.

Tabel 2. Deskripsi Hasil Belajar Siswa Kelas Eksperimen dan Kelas Kontrol

\begin{tabular}{lcc}
\hline \multirow{2}{*}{ Statistik } & \multicolumn{2}{c}{ Nilai Statistik } \\
\cline { 2 - 3 } & $\begin{array}{c}\text { Kelas } \\
\text { Eksperimen }\end{array}$ & $\begin{array}{c}\text { Kelas } \\
\text { Kontrol }\end{array}$ \\
\hline Jumlah sampel & 30 & 30 \\
Nilai terendah & 50 & 45 \\
Nilai tertinggi & 90 & 90 \\
Nilai rata-rata & 79,11 & 73,03 \\
Standar Daviasi & 10,34 & 13,76 \\
\hline
\end{tabular}

Tabel 3. Kategori Ketuntasan Hasil Belajar Kelas Eksperimen dan Kelas Kontrol

\begin{tabular}{cccccc}
\hline \multirow{2}{*}{ Nilai } & Kriteria & \multicolumn{2}{c}{ Eksperimen } & \multicolumn{2}{c}{ Kontrol } \\
\cline { 3 - 6 } & Ketuntasan & Frekuensi & Persentase & Frekuensi & Persentase \\
\hline$\geq 75$ & Tuntas & 25 & $83,33 \%$ & 23 & $76,67 \%$ \\
$<75$ & Tidak Tuntas & 5 & $16,67 \%$ & 7 & $23,33 \%$ \\
\hline
\end{tabular}

Tabel 4. Kriteria N-Gain siswa kelas eksperimen dan kontrol

\begin{tabular}{lcccccc}
\hline \multirow{2}{*}{ Kelas } & \multicolumn{4}{c}{ Perolehan N-Gain } \\
\cline { 2 - 7 } & \multicolumn{3}{c}{ Frekuensi } & \multicolumn{3}{c}{ Persentase (\%) } \\
\cline { 2 - 7 } & Tinggi & Sedang & Rendah & Tinggi & Sedang & Rendah \\
\hline Ekspeimen & 20 & 10 & 0 & 66.67 & 33.33 & 0,00 \\
Kontrol & 10 & 19 & 1 & 33.33 & 63.33 & 3.33 \\
\hline
\end{tabular}

Berdasarkan kriteria N-Gain menunjukkan bahwa perolehan N-Gain dengan kategori tinggi memiliki frekuensi lebih tinggi pada kelas eksperimen yaitu sebesar 20 atau $66,67 \%$ sedangkan pada kelas control hanya sebesar 10 atau 33,33\%.

\section{Hasil Pengujian Hipotesis}

Nilai N-Gain yang diperoleh dari data pretest dan posttest kemudian dianalisis inferensial dengan taraf signifikan $\alpha=0,05$. Pada uji normalitas, kelas eksperimen memiliki $\chi^{2}$ hitung $<$ $\chi_{\text {tabel, }}^{2} \quad 6,98<7,815$, sedangkan kelas kontrol memiliki $\chi^{2}$ hitung $<\chi_{\text {tabel }}^{2}$,
$4,689<7,815$, yang berarti bahwa data hasil belajar siswa kelas eksperimen dan kelas kontrol terdistribusi normal. Pada pengujian homogenitas, diperoleh nilai $F_{\text {hitung }}=1,68<\mathrm{F}_{\text {tabel }}=1,86$, yang berarti bahwa data berasal dari varians yang homogen.

Uji hipotesis hasil belajar siswa yang menggunakan uji-t, diperoleh $\mathrm{t}_{\text {hitung }}=3,002$. Pada taraf signifikansi $\alpha=0,05$ dengan $\mathrm{dk} 58$, diperoleh $\mathrm{t}_{\text {tabel }}=2,0017$. Oleh karena nilai $t_{\text {hitung }}>\mathrm{t}_{\text {tabel }}$, maka $\mathrm{H}_{1}$ diterima dan $\mathrm{H}_{0}$ ditolak. 


\section{B. Pembahasan}

Berdasarkan hasil analisis data deskriptif pada tabel 2 terlihat bahwa nilai terendah dan tertinggi untuk pretest pada kelas eksperimen yakni 0 dan 45 lebih rendah dibandingkan nilai terendah dan tertinggi untuk pretest pada kelas kontol yakni 5 dan 45 . Begitupun untuk nilai rata-rata pretest pada kelas eksperimen awalnya lebih rendah yaitu 16,56 dibandingkan nilai rata-rata pretest untuk kelas control yaitu 25,27. Namun, setelah digunakan media peta konsep melaui model pembelajaran kooperatif tipe TPS pada kelas eksperimen dan model pembelajaran kooperatif tipe TPS dengan media power point pada kelas kontrol, terlihat hasil yang sangat berbeda. Dimana nilai terendah dan tertinggi untuk posttest pada kelas eksperimen yakni 50 dan 90 lebih tinggi dibandingkan nilai terendah dan tertinggi untuk posttest pada kelas kontrol yakni 45 dan 90.

Hasil belajar siswa juga dapat dilihat dari perolehan N-Gain pada tabel 4 yang menunjukkan bahwa hasil belajar siswa pada kelas eksperimen lebih tinggi dibandingkan dengan kelas kontrol. Diamana pada kelas eksperimen jumlah siswa yang memperoleh $\mathrm{N}$-Gain dengan kategori tinggi sebanyak 20 orang atau 66,67\%, kategori sedang sebanyak 10 orang atau 33,33\% dan kategori rendah sebanyak $0 \%$. Sedangkan pada kelas kontrol jumlah siswa yang memperoleh N-Gain dengan kategori tinggi sebanyak 10 orang atau 33,33\%, kategori sedang sebanyak 19 orang atau 63,33\%, dan dengan kategori rendah sebanyak 1 orang atau $3,33 \%$.
Tabel 3 menunjukkan bahwa ketuntasan hasil belajar peserta didik pada materi hidrokarbon untuk kelas kesperimen telah memenuhi kriteria ketuntasan kelas yang ditetapkan sekolah yakni $80 \%$, sedangkan untuk kelas kontrol tidak memenuhi kriteria ketuntasan kelas, karena tinggakat ketuntasan pada kelas kontrol hanya sebesar 76,67\%.

Analisis inferensial untuk hasil belajar siswa menunjukkan data terdistribusi normal pada masingmasing kelas eksperimen dan kelas kontrol, dan juga dinyatakan berasal dari populasi yang homogen. Sedangkan, pada pengujian hipotesis memberikan hasil bahwa ada pengaruh media peta konsep melalui model pembelajaran koperatif tipe think pair share terhadap hasil belajar siswa. Hal ini dibuktikan dengan analisis deskriptif yang telah diuraikan sebelumnya.

Penggunaan media peta konsep melalui model pembelajaran kooperatif tipe TPS memberikan hasil belajar yang lebih baik. Hal ini membuktikan bahwa ada peningkatan penguasaan peserta didik terhadap materi pembelajaran yang disajikan, karena selama proses pembelajaran berlangsung siswa lebih mudah memahami materi pelajaran yang disampaikan selain itu dengan menggunakan model pembelajaran kooperatif tipe TPS mampu melibatkan peserta didik secara aktif dalam proses pembelajaran di kelas. Hal ini dapat dilihat dari tahapantahapan pembelajaran yang ada di dalamnya. Pada tahap awal guru memberikan penjelasan materi 
pelajaran melalui peta konsep, kemudian guru meminta siswa untuk memikirkan (Think) sendiri jawaban dari LKS yang diberikan. Kemudian setelah itu guru meminta siswa untuk mendiskusikan jawaban mereka dengan pasangan mereka (Pair) yang telah dibentuk secara homogen. Setelah diskusi berpasangan, siswa kemudian memdiskusikan lebih lanjut hasil kerja mereka kepada teman sekelas mereka (Share), sehingga memalui diskusi kelas ini mereka bisa salaing melengkapi jawaban mereka sehingga hal-hal yang belum mereka pahami saat berdiskusi kelompok dapat mereka pahami.

Dengan menggunakan media peta konsep siswa lebih mudah memahami materi pelajaran yang disampaikan, hal ini dikarenakan panyajian materi melalui peta konsep jauh lebih singkat dan tersusun secara sistematis dibandingkan dengan penayajian materi melalui power point biasa. Selain itu dengan media pata konsep dapat dengan mudah terlihat hubungan antar materi yang satu dengan materi yang lain.

Pada kelas kontrol yang diajar tanpa menggunakan media peta konsep melainkan hanya menggunakan Power point, yang menyababkan aktivitas siswa dalam mengamati penyampaian materi oleh guru menjadi kurang. Hal ini disebabkan karena pada slide power point banyak terdapat tulisan materi sehingga siswa menjadi cepat bosan dalam memperhatikan penjelasan guru. Selain itu siswa juga sudah terbiasa diajar dengan menggunakan power point yang menyebabkan siswa menjadi kurang memperhatikan dengan baik. Menyebabkab hasil belajar siswa kelas kontrol lebih rendah dari pada hasil belajar siswa kelas eksperimen.

Pengguaan media peta konsep dapat memberikaan hasil yang lebih tinggi, baik dari hasil belajar maupun aktivitas siswa dibandingkan dengan menggunakan power point biasa. Hal ini disebabkan karena dengan menggunakan media peta konsep pada saat penyampaian materi siswa lebih mudah untuk memahami materi pelajaran yang disampaikan oleh guru, karena dengan media peta konsep penyampaian konsep-konsep umum dari materi dapat dilakukan dengan cara sederhana dan mudah dipahami. Selain itu dengan media peta konsep dapat dilihat dengan mudah hubungan antara konsep yang satu dengan konsep yang lain sehingga ketika siswa belajar suatu konsep maka mereka mengetahui konsep apa yang harus mereka ketahui sebelum mempelajari konsep tersebut. Penggunaan media peta konsep ini adalah hal baru bagi mereka sehingga dapat merangsang rasa keingintahuan mereka dalam belajar. Sedangkan dengan menggunakan power point panyampaian materi cenderung berupa tulisan yang relatif panjang sehingga siswa menjadi cepat bosan saat proses pembelajaran. Power poin ini juga tidak menunjukkan hubungan antar satu konsep dengan konsep yang lain sehingga ketika suatu konsep yang membutuhkan pemahaman dari konsep yang lain siswa menjadi kesulitan untuk memahami konsep tersebut. Pengguaan power pont relatif biasa menurut mereka karena benyak mata 
pelajaran mereka yang diajarkan dengan power point.

\section{KESIMPULAN DAN SARAN}

\section{A. Kesimpulan}

Berdasarkan hasil analisis data dan pembahasan dapat disimpulkan bahwa $\mathrm{H} 0$ ditolak dan $\mathrm{H} 1$ diterima yang berarti bahwa terdapat pengaruh yang signifikan penggunaan media peta konsep melalui model pembelajaran kooperatif tipe TPS terhadap hasil belajar kelas X SMA Negeri 1 Liiriaja.

\section{B. Saran}

Berdasarkan hasil penelitian yang diperoleh dari penelitian ini, maka dikemukakan saran-saran yaitu: Guru diharapkan dapat mengatur waktu dengan baik khususnya pada tahap share karena akan membutuhkan banyak waktu dalam diskusi kelas tersebut. Guru diharapkan dapat mengontrol kelas dengan baik khususnya pada tahap share karena banyak siswa yang ingin menyampaikan hasil diskusi mereka.

\section{DAFTAR PUSTAKA}

Aqib, Zainal. 2014. Model-Model, Media dan Strategi Pembelajaran Kontekstual (Inovatif). Bandung: CV. Yrama Widya.

Kardiasih, Ayu, I Wyn Suwatra, dan Ni Kt Suarni. 2014. Implementasi Stategi TPS dalam Pembelajaran IPA dengan Menggunakan Peta Konsep Sebagai Upaya Meningkatkan Aktivitas dan Hasil Belajar Siswa Kelas V. Jurnal PGSD. Vol. 1. No. 1. Singaraja: Universitas Pendidikakan Ganesha.

Slavin, Robert E. 2009. Cooperative Learning. Bandung: Nusa Media.

Sugiono. 2012. Statistika Untuk Penelitian. Bandung: Alfabeta.

Yogihati, C.I.. 2010. Peningkatan Kualitas pembelajaran Fisika Umum Melalui Pembelajaran Bermakna dengan Menggunakan Peta Konsep. Jurnal Pendidikan Fisika Indonesia. Vol. 6. No. 1. Malang: Universitas Negeri Malang. 